

\section{DISCLAIMER}

This report was prepared as an account of work sponsored by an agency of the United States Government. Neither the United States Government nor any agency Thereof, nor any of their employees, makes any warranty, express or implied, or assumes any legal liability or responsibility for the accuracy, completeness, or usefulness of any information, apparatus, product, or process disclosed, or represents that its use would not infringe privately owned rights. Reference herein to any specific commercial product, process, or service by trade name, trademark, manufacturer, or otherwise does not necessarily constitute or imply its endorsement, recommendation, or favoring by the United States Government or any agency thereof. The views and opinions of authors expressed herein do not necessarily state or reflect those of the United States Government or any agency thereof. 


\section{DISCLAIMER}

Portions of this document may be illegible in electronic image products. Images are produced from the best available original document. 
Reference to a company or product name does not imply approval or recommendation of the product by Union Carbide Corporation or the U.S. Energy Research and Development Administration to the exclusion of others that may meet specifications.

Printed in the United States of America. Available from

National Technical Information Service

U.S. Department of Commerce

5285 Port Royal Road, Springfield, Virginia 22161

Price: Printed Copy $\$ 4.00$; Microfiche $\$ 2.25$

This report was prepared as an account of work sponsored by the United States Government. Neither the United States nor the Energy Research and Development Administration, nor any of their employees, nor any of their contractors, subcontractors, or their employees, makes any warranty, express or implied, or assumes any legal liability or responsibility for the accuracy, completeness or usefulness of any information, apparatus, product or process disclosed, or represents that its use would not infringe privately owned rights. 


\title{
HIGH-STIFFNESS GRAPHITE FIBER/EPOXY COMPOSITE GRINDING QUILL FOR A VERTICAL TURNING MACHINE TOOL
}

\author{
L. Kovach \\ C. E. Knight, Jr
}

Fabrication Systems Development Department

$Y-12$ Development Division

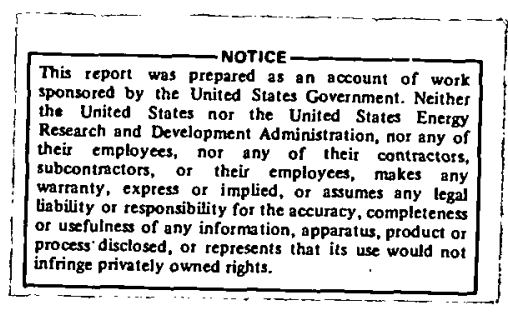

Oak Ridge Y-12 Plant

P. O. Box Y, Oak Ridge, Tennessee $\mathbf{3 7 8 3 0}$

Prcpared for the US Energy Research and Development Administration

Undor US Government Contract W-7405-eng-28

DISTRIBUTION OF THIS DOCUMENT IS UNCRMTTES 


\section{ABSTRACT}

Modification of an Ex-Cell-O vertical turning machine into a precision contour grinder was effected by the use of a graphite fiber/epoxy composite as the structural support (termed a Quill) for the grinding head. 


\section{CONTENTS}

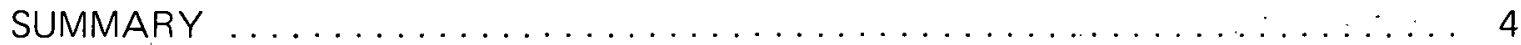

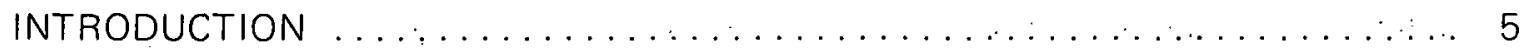

SPECIAL COMPOSITE GRINDING QUILL $\ldots \ldots \ldots \ldots \ldots \ldots \ldots \ldots \ldots$

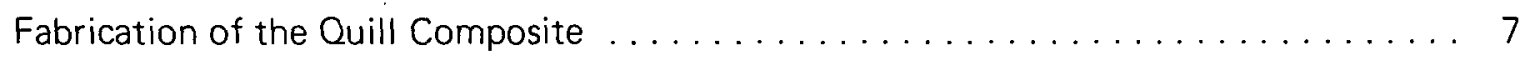

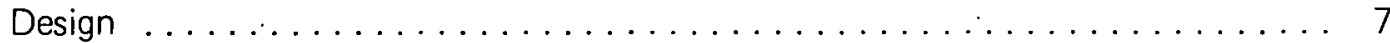

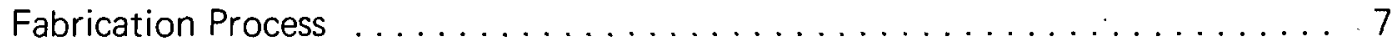

Attaching the Quill to the Ex-Cell-O Machine $\ldots \ldots \ldots \ldots \ldots \ldots \ldots \ldots \ldots \ldots$

Testing the Quill . . . . . . . . . . . . . . . . . . . . . . . . . . . 12

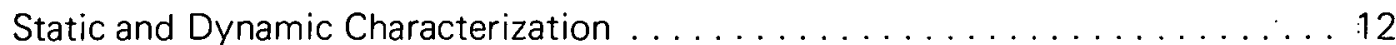

Test Grinding . . . . . . . . . . . . . . . . . . . . . . . . . 13

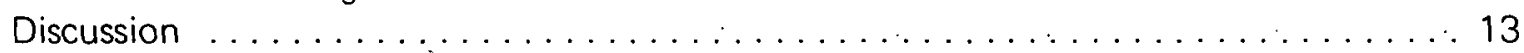

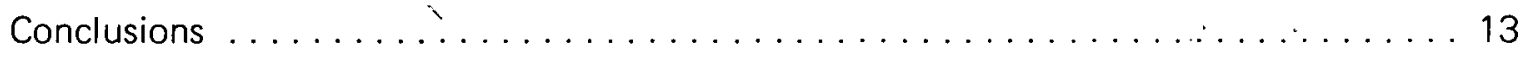

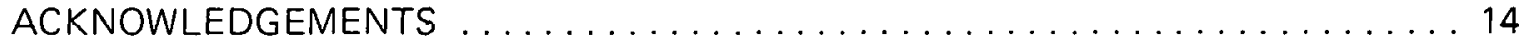




\section{SUMMARY}

Superior strength, stiffness, light weight, and damping properties of composites qualify them as possible materials for use in machine-tool applications. Modification of an existing Ex-Cell-O vertical turning machine into a precision contour grinder involved the need for a structural support for the grinding head. This need was fulfilled by the fabrication of a conical graphite fiber/epoxy composite Quill [25.4 mm (1 in) thick by 1.143 m (45 in) long], with diameters of 304.8 and $172.7 \mathrm{~mm}$ (12 and $6.8 \mathrm{in})$ at the two ends.

In fabricating the Quill, Thornel 755 graphite yarn, with an elastic modulus of approximately $517.1 \mathrm{GPa}\left(75 \times 10^{6} \mathrm{psi}\right)$, was employed as the reinforcement material with a DER 332/T-403 room-temperature-curing epoxy resin system as the binder. A 0/90-degree fiber pattern was used, whereby one circumferential layer was applied per each nine longitudinalily oriented layers. I he latter layers consisted of manually applied gores cut to size and shape. from unidirectionally wound, single-layer "blankets". Match-die pressing techniques after the addition of each four to five layers were used to squeeze out excess resin. The resultant structure had a yarn content of $52.5 \mathrm{vol} \%$ and a calculated elastic modulus in the axial direction of $241.32 \mathrm{GPa}\left(35 \times 10^{6} \mathrm{psi}\right)$.

After being attached to the Ex-Cell-O machine, the Quill and all its grinding attachments were characterized both statically and dynamically. The characterization work concluded that the Quill was stiffer than the rest of the grinder. head assembly and that, with the installed Quill, the grinding machine would perform well during actual operation. 


\section{INTRODUCTION}

The high stiffness-to-weight ratio, high strength-to-weight ratio, and vibration-damping properties of many composites make them possible materials for use in machine-tool applications. Conceivably, by the proper utilization of these materials and their properties, improved designs could be formulated to produce tools having less chatter and vibration.

The opportunity to investigate the performance of a composite in a machine-tool application arose in the Oak Ridge Y-12 Plant(a) Fabrication Division. Work had been underway to modify an existing Ex-Cell-O vertical turning machine into a precision contour grinder. One of the primary machine components involved in this modification was the structural support for the grinding head. This support was designated as the "Quill". Figure 1, which will enable the reader to better visualize the Quill and its function, shows the Quill mounted in position on the Ex-Cell-O machine. Seen here is a graphite/epoxy composite structure [ $25.4 \mathrm{~mm}(1 \mathrm{in})$ thick by $1.143 \mathrm{~m}$ ( $45 \mathrm{in}$ ) long] , with outer diameters of 304.8 and $172.7 \mathrm{~mm} \mathrm{(12} \mathrm{and} 6.8 \mathrm{in}$ ) at the two ends. There is a drive shaft inside the conical structure which rotates a grinding wheel located at the bottom.

Any deflection, expansion, or vibration of the Quill support leads to inaccuracies in the performance of the grinder. It was felt that a graphite fiber-reinforced structure would be specifically suited for this application, in that it would have a low thermal expansion coefficient, would be light weight, have superior stiffness, and have good vibration damping characteristics. Thornel $75 \mathrm{~S}$ graphite yarn with an elastic modulus of $537.8 \mathrm{GPa}(78 \times 106$ psi) was used as the reinforcement material to fabricate the Quill structure. In Table 1, the basic properties of a Thornel $75 \mathrm{~S}$ graphite/epoxy composite containing $60 \mathrm{vol} \%$ fiber are compared with steel and tungsten carbide.

Table 1

BASIC PROPERTIES OF A THORNEL 75S GRAPHITE/EPOXY COMPOSITE COMPARED TO STEEL AND TUNGSTEN CARBIDE

\begin{tabular}{lccc}
\hline \multicolumn{1}{c}{ Composite Property (1) } & Thum itel 75S/Epoxy & Steel & Tungsten Carbide \\
\hline Elastic Modulus $\left(\mathrm{GPa} / \mathrm{psi} \times 10^{6}\right)$ & $275.8 / 40$ & $206.8 / 30$ & $\sim 689.5 / \sim 100$ \\
Density $\left(\mathrm{g} / \mathrm{cm}^{3}\right.$ ) & 1.5 & 7.8 & 15.8 \\
Stiffness-to-Weight Ratio & 18.8 & 2.70 & 4.45 \\
Thermal Expansion Coefficient & 0 & $15.1 \times 10^{-6} / 8.4 \times 10^{-6}$ & $7.38 \times 10^{-6} / 4.1 \times 10^{-6}$ \\
$\quad\left(\mathrm{~m} / \mathrm{m} /{ }^{\circ} \mathrm{C} /\right.$ in/in/ ${ }^{\circ} \mathrm{F}$ ) & 20 & 1 & \\
Damping Factor, Relative & & 1 & \\
\hline
\end{tabular}

(1) Composite contains 60 vol \% fiber.

(a) Operated by the Union Carbide Corporation's Nuclear Division for the US Energy Research and Development Administration. 


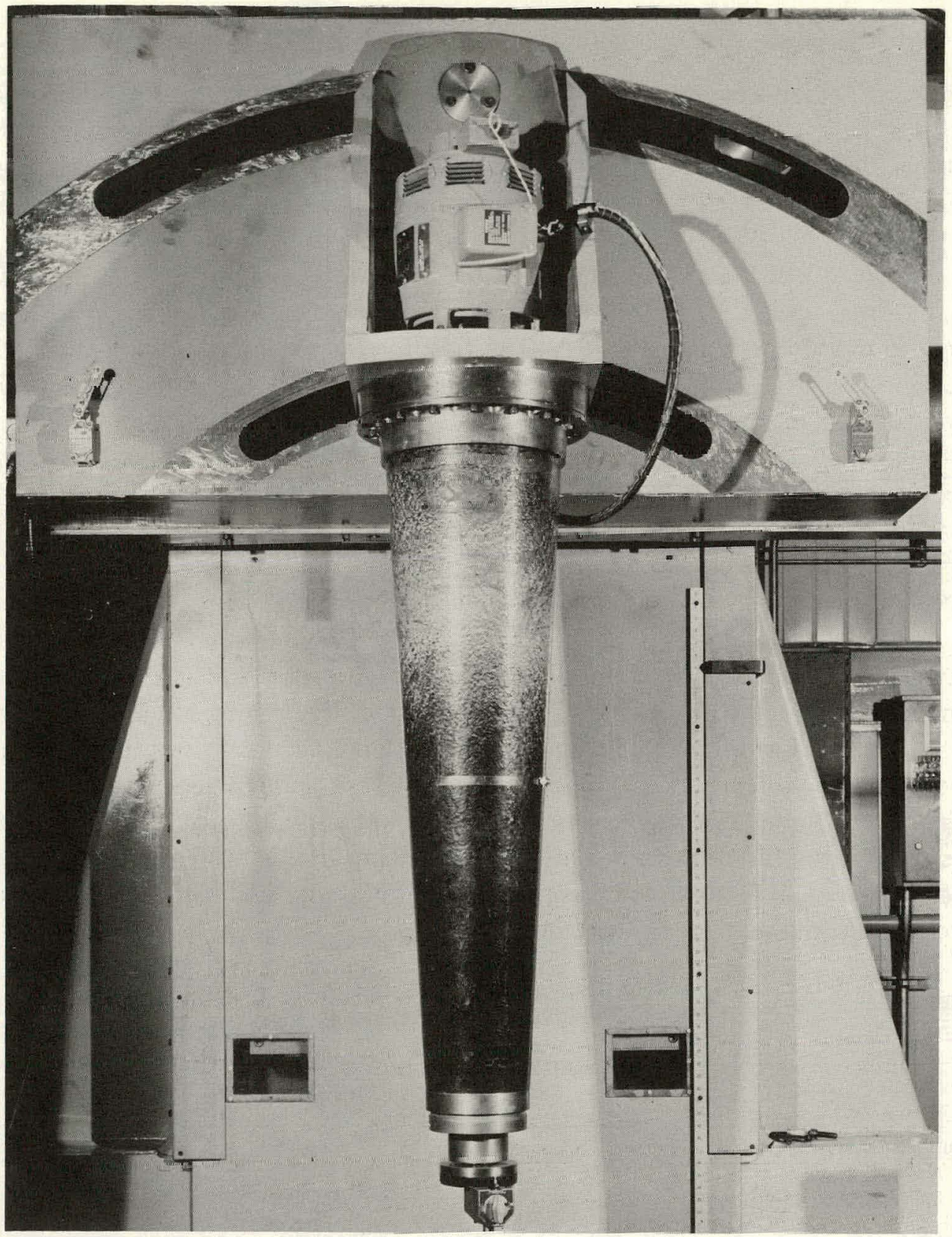

Figure 1. THF DUILL MOUNTCD ON THE EX-CELL-O MACHINE.

158747

Several items might be pointed out here. The graphite/epoxy has an clastic modulus between that of steel and tungsten carbide and it has a stiffness-to-weight ratio seven times better than steel and four times better than tungsten carbide. Had the Quill been made of tunysten carbide it would have weighed $317.5 \mathrm{~kg}(700 \mathrm{lb})$ instead of $31.75 \mathrm{~kg}(70 \mathrm{lb})$. The damping-factor values shown are only relative and are based on data found in the literature. Apparently, the graphite/epoxy is 20 times better than steel. 


\section{SPECIAL COMPOSITE GRINDING OUILL}

\section{FABRICATION OF THE QUILL COMPOSITE}

\section{Design}

Since, in making the Quill, the objective was to have a resultant structure with a high axial elastic modulus and a high volume fraction of fibers, it was decided to use a 0/90-degree fiber pattern whereby one circumferential layer was applied per each nine longitudinally oriented layers. The longitudinally oriented layers consisted of manually applied gores cut to size and shape from unidirectionally wound "blankets". It was also decided to use compaction techniques during fabrication, so that the resin squeeze out would serve to increase the fiber content. This compaction was done by a match-die pressing operation. In order to eliminate thermal stresses and the increased chances of having flaws in the structure, a room-temperature-curing epoxy resin was used as the binder.

\section{Fabrication Process}

Fabrication of the Quill might best be described by discussing the processing operations in sequence. The first processing step was to make blankets, whereby the yarn was wound onto a cylindrical mandrel in a circumferential direction (seen in Figure 2). The mandrel employed was $431.8 \mathrm{~mm}$ (17 in) in diameter by $1.219 \mathrm{~m}$ (48 in) long and was covered with

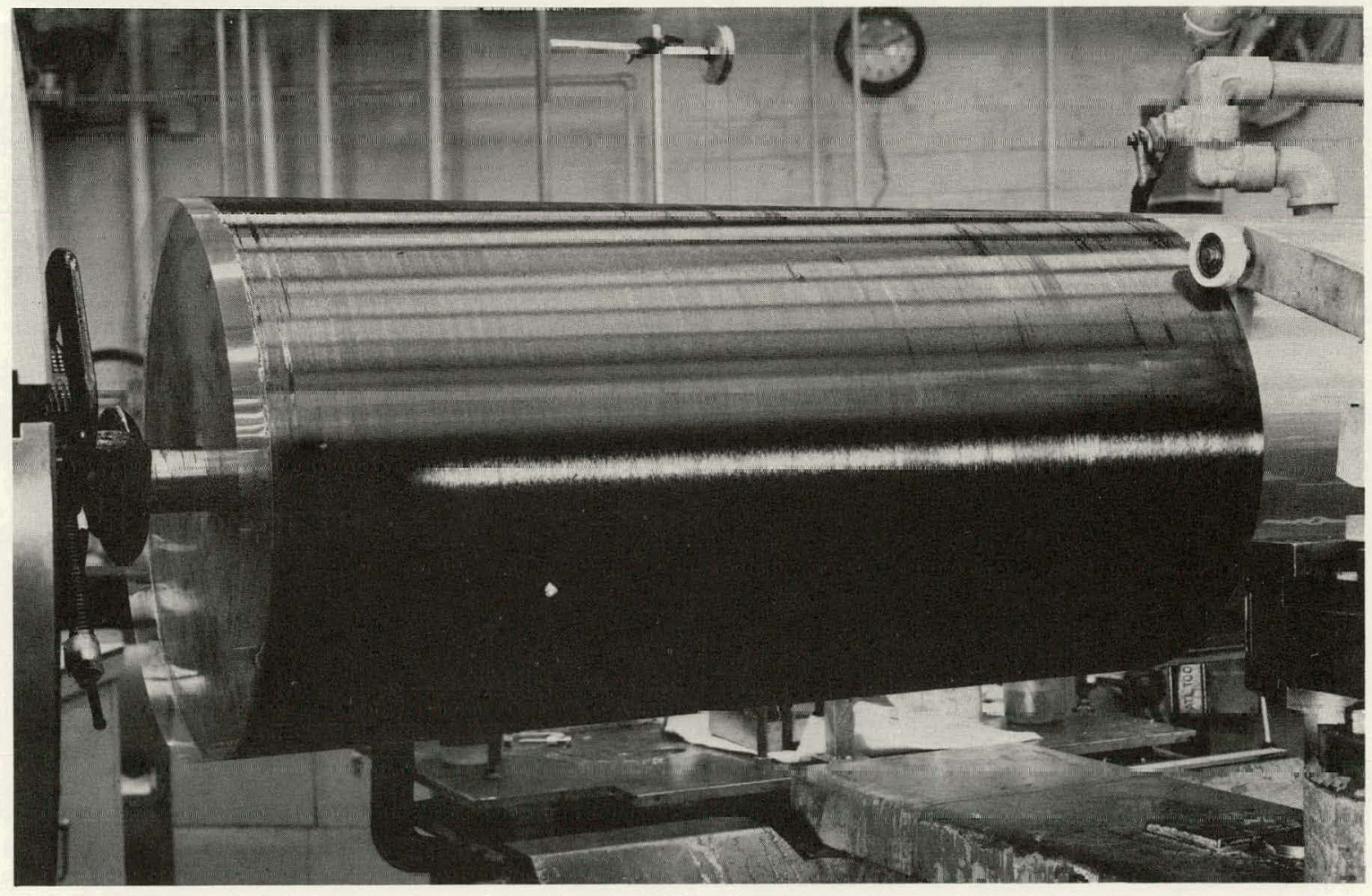

Figure 2. WINUING A UNIDIRECTIONAL BLANKET. 
a 2-mil thick sheet of Mylar prior to winding. Efforts were made to limit the resin content of the blankets to approximately $40 \mathrm{wt} \%$. At this point they had the right degree of tackiness and could be readily manipulated by the operators in the subsequent operations. It was found that a more uniform blanket was obtained by using a roller compactor during winding.

Upon being removed from the mandrel, a blanket was unrolled and flattened, and its exposed surface was covered with another sheet of 2-mil-thick Mylar. Blankets were cut into gores with the aid of a triangular template. This step is shown in Figure 3. Gores were cut so that the fibers were aligned parallel to the axis of the conical mandrel used to fabricate the Quill. Three gores were used for each layer. These gores were either used immediately or were sealed in plastic bags for storage in a freezer. Efforts were made to minimize the time period the gores remained outside the freezer so that they would not cure and lose their usefulness. A DER 332/T-403 epoxy resin system was selected for this work because its working life was of sufficient duration to permit the varinus processing operations to be carried out.

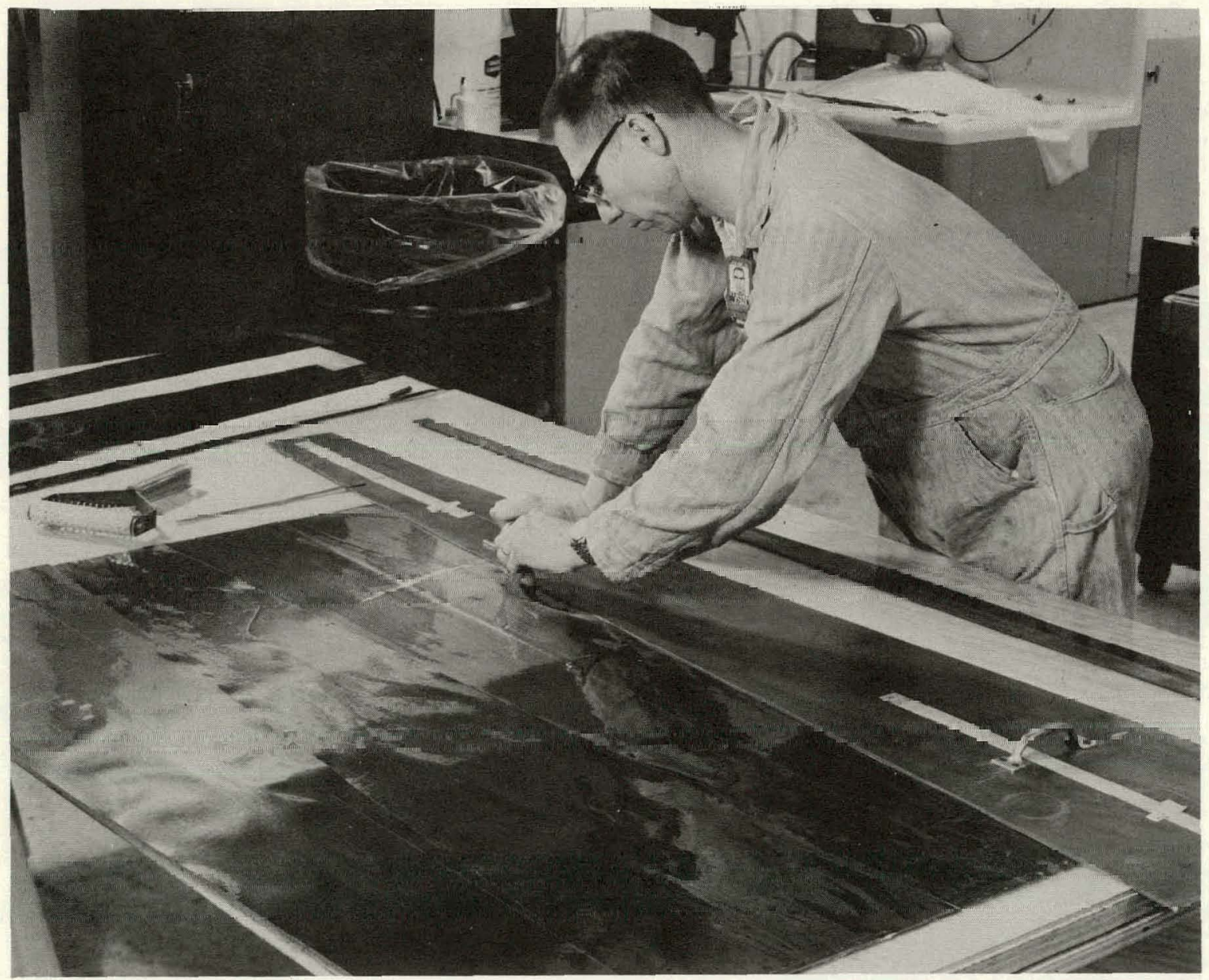

Figure 3. GORE PREPARATION. 
The mandrel used for fabricating the Quill was $1.270 \mathrm{~m}$ (50 in) long, with upper and lower diameters of 261.4 and $113.3 \mathrm{~mm}$ (10.29 and $4.46 \mathrm{in}$ ), respectively, and it had a $3020^{\prime \prime}$ taper. Prior to applying the yarn layers, the mandrel was sprayed with Teflon mold release and was covered with a 2-mil-thick sheet of Mylar. The butt joint between the first two gores applied to the mandrel was positioned at a specific point of reference. As successive layers were added, care was taken to position the gores so that the butt joints were staggered. Figure 4 shows the Quill in the process of being fabricated, with one of the longitudinal layers exposed. In Figure 5, another processing step is shown; namely, the winding of a circumferential layer.

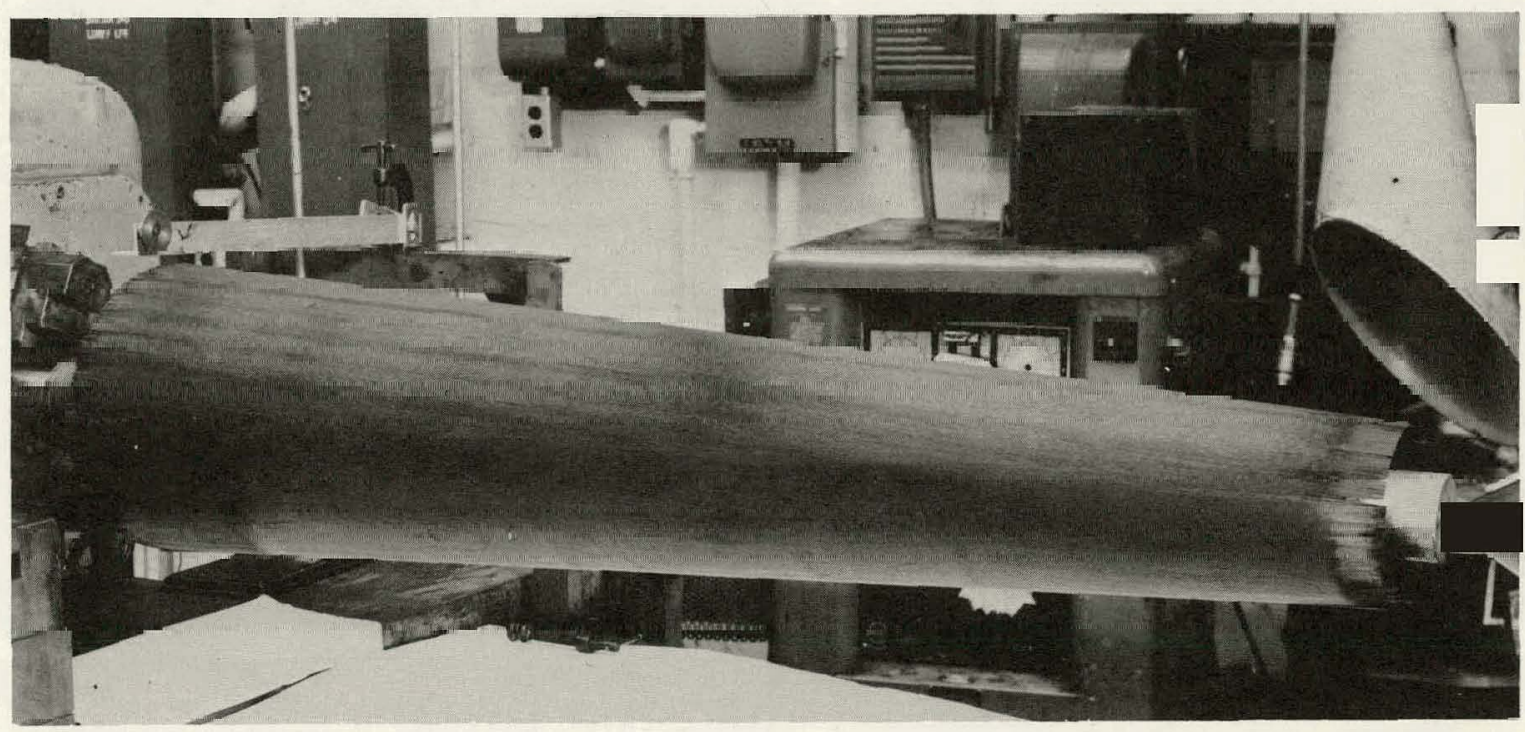

150487

Figure 4. LONGITUDINAL LAYER APPLIED TO THE QUILL.

It was decided to compact the Quill after the addition of every fourth and ninth longitudinal layers. In preparing to press the conical mandrel in the female die, it was covered with a perforated sheet of 2-mil-thick Mylar, two layers of green felt cloth, and then another sheet of 2-mil Mylar. Figure 6 shows the Quill cone about to be lowered into the female die. The die was a block of graphite, $1.829 \mathrm{~m}(6 \mathrm{ft})$, high by $609.6 \mathrm{~mm}(2 \mathrm{ft}) \mathrm{in}$ diameter, with a cavity tapered to match the conical mandrel. A hydraulic jack was used to provide the necessary compacting force; which, in this case, was $181 / 2$ tons. The compaction pressure normal to the surtace of the cone (assuming the absence of friction) was calculated to be $3309.5 \mathrm{kPa}$ (480 psi). At this level there was sufficient squeeze out of the resin to wet the two layers of cloth covering the cone. Two time periods were used in the pressing operation. After each fourth longitudinal layer was added, the cone was pressed for six hours; and, after each ninth longitudinal layer, the cone was permitted to stay in the die overnight for a period of 10 to 14 hours. The outer layers of the cone, after six hours of pressing, were found to be soft and tacky. For the longer retention periods, the outer layers were in a more advanced state of cure, but they still retained some tack. Fortunately, provision was made in the design of the equipment for a reverse-operating jack. It took about as much force to pull the conical mandrel out of the die as it took to compact it. 


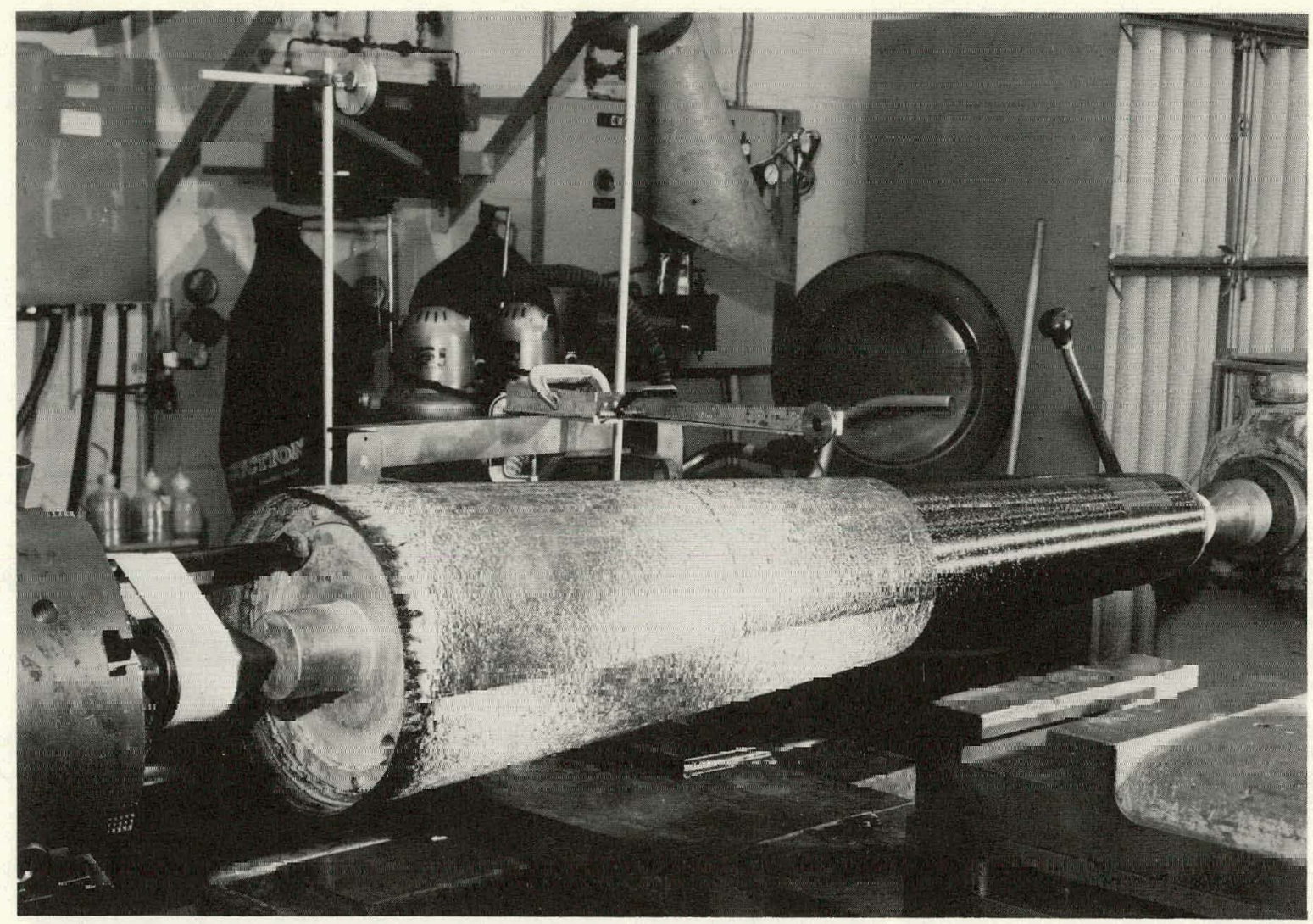

Figure 5. WINDING A CIRCUMTCICNTIAL LAYER.

150131

After numerous repetitions of the previously described operations, the Quill was completed. It took 171 lavers to make the 25.4-mm (1-in)-thir.k strurture, which consumed approximately $22.7 \mathrm{~kg}(50 \mathrm{lb})$ of graphite yarn. Wall-thickness measurements, as determined from $X$-ray photographs, showed a variation of $-0.457 \mathrm{~mm}(-18 \mathrm{mils})$ and $+0.330 \mathrm{~mm}(+13$ mils) from the overall average thickness. [The average thickness of a laver was calculated to be $0.150 \mathrm{~mm}$ (5.9 mils).] From an analysis of the test specimens machined from the ends of the Quill, the fiber content was determined to be $64.1 \mathrm{wt} \%$ and the density to be $1.492 \mathrm{~g} / \mathrm{cm}^{3}$. Based on these data, calculations indicated the yarn content to be $52.5 \mathrm{vol} \%$ and the elastic modulus in the axial direction to be approximately $241.32 \mathrm{GPa}\left(35 \times 10^{6}\right.$ psi).

\section{ATTACHING THE QUILL TO THE EX-CELL-O MACHINE}

Attachment of the Quill to the Ex-Cell-O machine head was accomplished with mating steel adapters, illustrated in the sketch of Figure 7 . The adapters were acid etched and then adhesively bonded into the Quill with an Epon 828/TETA epoxy resin system. This interfacing of the Quill with the machine is a crucial operation, since the lack of a good bond between the mating surfaces will lower the overall effective Quill stiffness and introduce inaccuracies in the performance of the grinding head. 

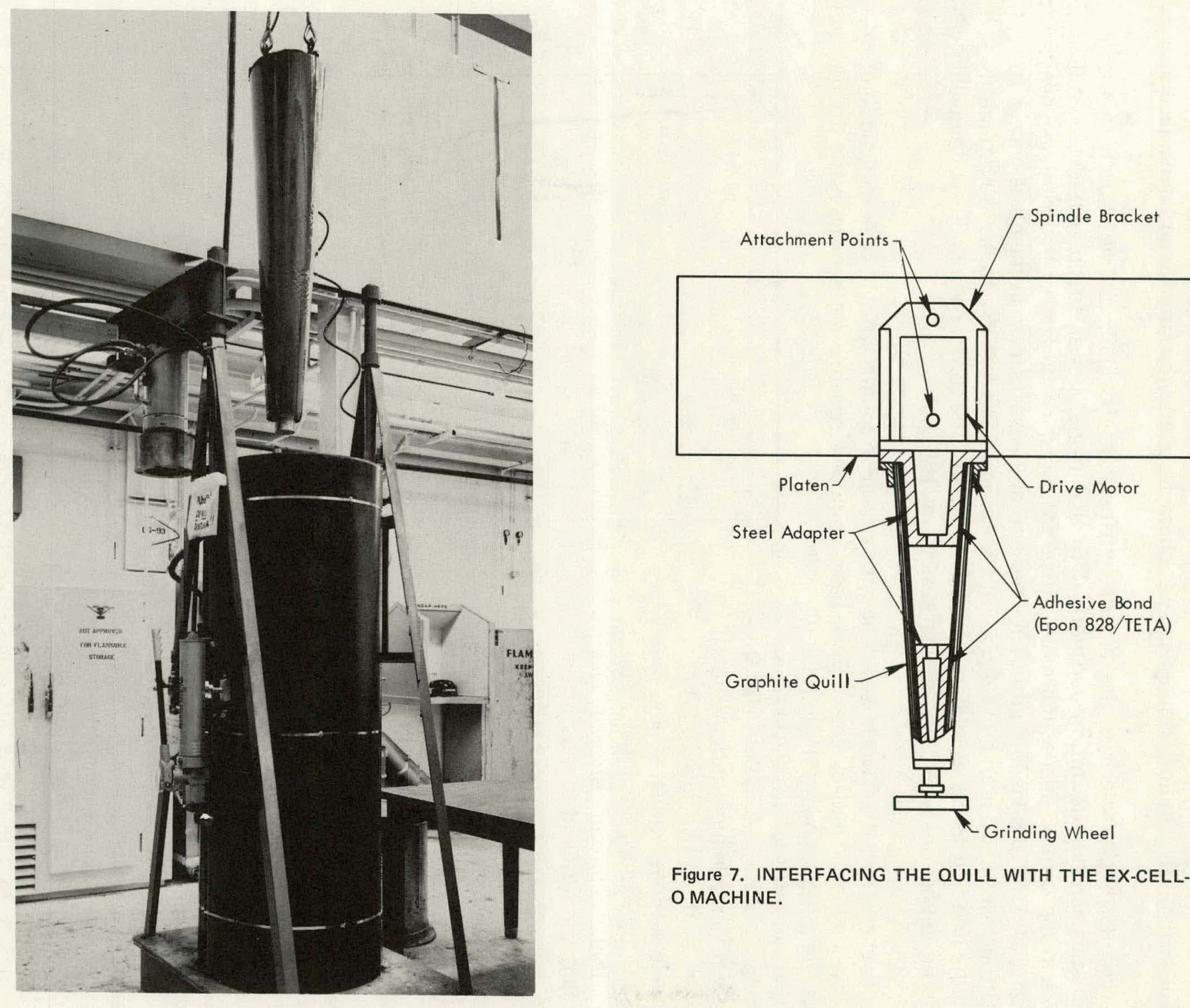

Figure 7. INTERFACING THE QUILL WITH THE EX-CELLO MACHINE.

Figure 6. COMPACTION OF THE QUILL.

150259 


\section{TESTING THE QUILL}

\section{Static and Dynamic Characterization}

In order to obtain basic data which would aid in the future design of composite structures, the Quill with all its grinding attachments was characterized both statically and dynamically.

The static tests characterized the flexural stiffness of the Quill assembly both in the plane-of-part-contour definition and normal to that plane. It was found that the overall stiffness in the contour plane (the most critical for contour accuracy) at the grinding-wheel location was $0.370 \mu \mathrm{m} / \mathrm{kg}(6.6 \mu \mathrm{in} / \mathrm{lb})$ for horizontal loads; stiffness in the plane normal to the contour was $0.806 \mu \mathrm{m} / \mathrm{kg}(14.4 \mu \mathrm{in} / \mathrm{lb})$. Expressing this value in another way, it means that if the grinding torces were less than $11.3 \mathrm{~kg}(25 \mathrm{lb})$, the contour errors due to the Quill and mount deflections would be less than $4.191 \mu \mathrm{m}$ (165 $\mu \mathrm{in})$.

Dynamic characterization work was done with a rotating spindle with no grinding loads and with low-load-level impact tests. Two basic spindle resonance frequencies were found present in the range of spindle operating speeds up to $2700 \mathrm{rpm}$ $(40 \mathrm{~Hz}$ at $2400 \mathrm{rpm}$ and $45 \mathrm{~Hz}$ at $2700 \mathrm{rpm})$. Spindle amplitudes were a maximum at these two speeds. (These are speed settings which should be avoided in operation, since they result in maximum contour errors.) Displacement of the Quill at its bottom end as a function of spindle speed is reported in the graph of Figure 8. Maximum displacements were 0.234 and $0.152 \mu \mathrm{m}$ (9.2 and $6.0 \mu \mathrm{in})$ at 2700 and $2400 \mathrm{rpm}(45$ and $40 \mathrm{~Hz})$, respectively.

Natural resonance frequencies, as determined by impact tests, were tound to be $62,80,90$, and $188 \mathrm{~Hz}$. The first flexural resonant frequency of the Quill was calculated at $91 \mathrm{~Hz}$.

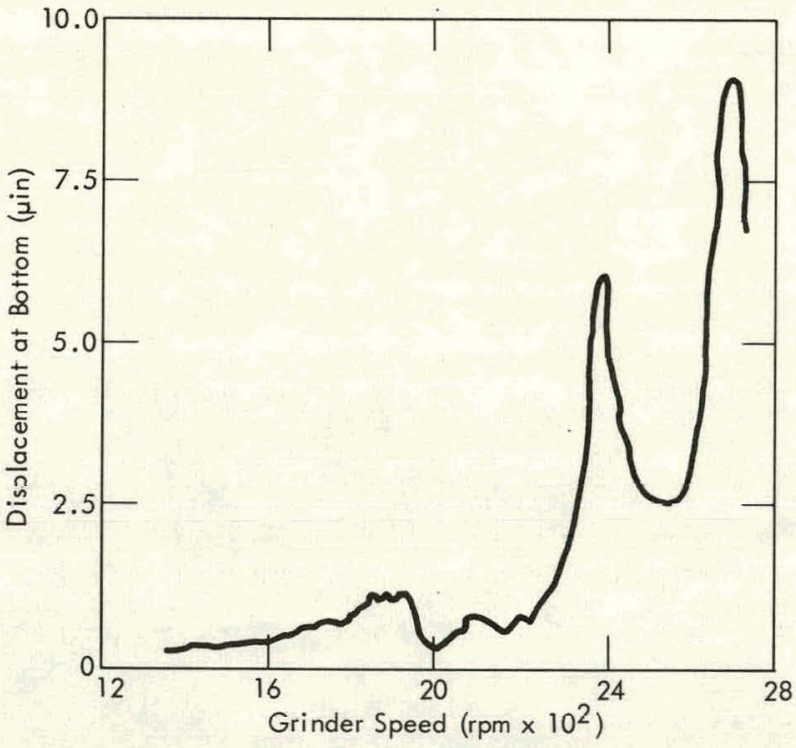

Figure 8. QUILL DISPLACEMENT AT THE BOTTOM END AS A FUNCTION OF THE SPINDLE SPEED.

In these measurements the 62 and $80-\mathrm{Hz}$ values are believed to be rigid body modes; and, thus, $90 \mathrm{~Hz}$ is the measured value of the first flexural critical.

In mapping vibration levels at the bottom of the Quill during an actual grinding operation, a maximum amplitude was found at a frequency of $60 \mathrm{~Hz}$. During this operation, cutting-spindle speeds ranged from 1500 to $2500 \mathrm{rpm}$ ( 25 to $\sim 42 \mathrm{~Hz}$ ) and table speeds were varied from 2 to $8 \mathrm{rpm}$. No measurable differences are evident over these spindle and table-speed ranges. It is believed that the $60-\mathrm{Hz}$ frequency in the spindle drive motor is exciting the $62-\mathrm{Hz}$ flexural resonant frequency of the Quill and resulting in the peak amplitude at $60 \mathrm{~Hz}$. 
From the dynamic characterization work conducted thus far, it was concluded that the Quill was stiffer than the remainder of the grinder-head assembly. Furthermore, any further reduction of spindle displacement will require improvements in other areas of the machine (eg, the machine frame rigidity and the interfacing brackets).

\section{Test Grinding}

Further testing of the grinder-head assembly involved grinding a graphite cylinder $685.8 \mathrm{~mm}$ (27 in) in diameter and $304.8 \mathrm{~mm}$ (12 in) high. Inspection results on the completed part indicated that the grinder had performed successfully. The outside diameters checked at various latitudes varied within $\pm 0.00762 \mathrm{~mm}$ ( $\pm 0.0003 \mathrm{in}$ ).

\section{DISCUSSION}

Approximately 60 pounds of Thornel $75 \mathrm{~S}$ graphite yarn and 8. man months of labor went into the fabrication of the Quill. The present price of Thornel $75 S$ yarn is $\$ 385$ per pound, which is relative expensive. In order for a composite structure (ie, the Quill) to be economically competitive with such conventional materials as steel or tungsten carbide, the price of the reinforcing yarn would have to be reduced by a factor of 10 . However, with the continuous advent of new and improved tilamentary materials, the prospect of getting less expensive yarns with superior properties appears promising. (b)

As far as fabrication labor costs are concerned, additional development efforts will be necessary to find ways of eliminating many of the manual operations inherent in this work.

\section{CONCLUSIONS}

Conclusions of the work covered in this report are:

1. The graphite composite Quill is well suited for the precision contour grinding modification to the Ex-Cell-O machine.

2. Characterization and checkout of the installed Quill indicate that a very good performance can be expected in actual operation.

3. Further improvement in the performance of the Ex-Cell-O contour grinder will require upgrading of other components of the machine, such as the machine hydraulics and frame rigidity.

4. Where special properties required for high performance are the overriding criterion, composite structural members may be employed in precision machine tool applications.

(b) Union Carbide Corporation has recently announced the development of a pitch precursor graphite yarn with a 70 -90-million-psi modulus to be sold for under $\$ 50$ a pound. 


\section{ACKNOWLEDGEMENTS}

The authors wish to acknowledge the many contributions that were made by several individuals involved in the design, fabrication, and test work associated with this project, especially
S. B. McSpadden
Y-12 Fabrication Division - Project Direction and
J. S. Hurst
Coordination
C. A. Begley
W. R. Hamilton
F. Holt
ORGDP Separation Systems Division - Dynamic Testing
R. E. Ziegler 


\section{Distribution}

Energy Research and Development Administration - Oak Ridge

Hickman, H. D.

Leed, R. E.

Zachry, D. S., Jr

\section{Lawrence Livermore Laboratory}

Bryan, J. B:

Chiao, T. T.

\section{Los Alamos Scientific Laboratory}

Zerwas, A. M.

\section{Oak Ridge Gaseous Diffusion Plant}

Begley, C. A.

Hamilton, T. H.

Holt; $F$

O'Kain, D. U.

Stief, S. S.

Waters, D. A.

Wilcox, W. J., Jr

Ziegler, R. E.

\section{Oak Ridge Y-12 Plant}

Alvey, H. E.

Babelay, E. F., Jr

Barkman, W. E.

Burditt, R. B.

Burkhart, L. E.

Butturini, W. G.

Dritt, W. S.

Foullk., D. L.

Fraser, R. J.

Fuis, F., Jr

Gritzner, V. B.

Hensley, C. E.

Huddleston, R. L.

Hurst, J. S.
Jones, F.W.

Kahl, K. G.

Keith, A.

Kite, H. T. (75)

Knight, C. E., Jr (15)

Kovach, L. (5)

Lundin, M. I.

McSpadden, S. B., Jr

Mills, J. M., Jr

Oliphant, G. W.

Parks, C. J.

Perry, A. E.

Phillips, L. R.

Post, D. W.

Smith, H. F., Jr

Smith, R. D.

Stoner, H. H.

Tewes, W. E.

Thompson, C. H.

Thompson, W. F:

Tilson, F. V.

Watkins, E. R.

Weathersby, W. E.

Webber, T. R.

White, B. J.

Whitson, W. K.

Whitten, L. G.

Wiley, J. H.

Yaggi, W. J./Googin, J. M.

$Y-12$ Central Files (5)

$Y-12$ Central Files (master copy)

$Y-12$ Central Files (route copy)

$Y-12$ Central Files (Y-12RC)

Zerby, C. D.

Paducah Gaseous Diffusion Plant

Millican, $R$.

Sandia - Albuquerque

Gerstle, F. P.

In addition, this report is distributed in accordance with the category UC-38, Engineering and Equipment, as given in the USERDA Standard Distribution Lists for Unclassified Scientific and Technical Reports, TID-4500. 